\title{
ENDIVIDAMENTO DOS ENTES SUBNACIONAIS E REGIME DE PRECATÓRIOS
}

\author{
Rodrigo Luís Kanayama \\ Advogado, Doutor em Direito pela UFPR e Professor \\ de Direito Financeiro da Faculdade de Direito da UFPR. \\ Fabrício Ricardo de Limas Tomio \\ Doutor em Ciência Política pela UNICAMP \\ e Professor de Ciência Política da Faculdade de Direito da UFPR. \\ Ilton Norberto Robl Filho \\ Advogado, Doutor em Direito pela UFPR e Professor da Faculdade \\ de Direito da UFPR e do Instituto Brasiliense de Direito Público (IDP).
}

Introdução - 1. A dívida pública - 2. O regime de precatórios na Constituição de 1988: 2.1 Alterações no regime ordinário de precatórios - Emendas Constitucionais n. 94 e 99 - Conclusão - Referências. 


\section{INTRODUÇÃO}

Atualmente, o excesso de endividamento dos entes subnacionais - em especial, dos Estados - é um dos pontos debatidos nos meios de comunicação e na doutrina jurídica. Grande parte da dívida consolidada estadual advém das dívidas judiciais, chamadas informalmente de precatórios. Ainda que a Constituição da República (CRFB) tenha sido emendada muitas vezes (citamos aqui as mais recentes Emendas Constitucionais: n. 62/2009, n. 94/2016 e n. 99/2017), por ausência da impositividade no pagamento das dívidas judiciais e por insuficiência do comprometimento dos governos, a dívida cresceu em patamares assustadores.

Parece sem solução a situação atual, sobretudo em razão da forte crise econômica que abate o país e os Estados da Federação. Na falta de recursos financeiros, as dívidas tendem a se acumular, e seu pagamento é postergado. Juros em razão da mora impactam ainda mais o erário, a ponto de serem propostas soluções constitucionais que, mesmo que se digam constitucionais, representarão insegurança jurídica, que prejudica o ambiente de negócios nacional.

Nesse sentido, pretendemos apresentar o cenário atual da dívida judicial dos Estados, demonstrando os impactos que a dívida provoca nas finanças públicas. Ainda, promover-se-á a apreciação das soluções possíveis propostas pelas recentes alterações trazidas pela Emenda Constitucional n. 99 (EC n. 99) e, em especial, a análise das possíveis alterações constitucionais futuras.

\section{A DÍVIDA PÚBLICA}

A dívida pública, em níveis prudentes, é possível, e, de certa forma, salutar. Um Estado que tenha capacidade de endividamento possui, no mesmo passo, crédito público, ou seja, detém confiança dos mercados nacional e internacional ${ }^{1}$. Ao contrário do que possa parecer, a obtenção de empréstimos, a fim de promover investimentos públicos duradouros, além de não haver vedação legal, também demonstra a competência do gestor público.

Além disso, a dívida pública é um instrumento de política monetária (disponibilidade e liquidez da moeda, redução da volatilidade etc.), de regulação da balança de pagamentos (transações e internalização de moedas estrangeiras) e de política fiscal (administração de déficits e superávits fiscais). Aqui, muitas vezes,

1 “La palabra 'crédito' deriva del latín creditum, y esta locución provice a su vez del verbo credere, que significa 'tener confianza o fe'. El termino 'público' hace referencia a la persona de aquel (Estado) que hace uso de la confianza en él depositada, pidiendo que se le entregen bienes ajenos en contra de la promessa de la ulterior restitución” (VILLEGAS, Héctor Belisario. Curso de finanzas, derecho financeiro y tributário. 9. ed. Buenos Aires: Astrea, 2009, p. 103). 
reside a confusão entre dívida pública bruta (Dívida Bruta do Governo Geral DBGG) e líquida (Dívida Líquida do Setor Público - DLSP). A primeira é o total da dívida do setor público não financeiro e do Banco Central com o sistema financeiro, enquanto a segunda é a dívida bruta menos a soma dos créditos do setor público não financeiro e do Banco Central (ativos e passivos financeiros do Banco Central, incluindo a base monetária). Como o foco deste texto é a dívida judicial do Estado, precatório, sobretudo dos entes subnacionais, neste momento basta localizá-lo no conjunto da dívida líquida (DLSP)².

Construção de obras vultosas, investimentos perenes, melhorias sociais são motivos para que o Estado contraia empréstimos, sejam eles por meio de disposição de títulos públicos às pessoas privadas, mediante remuneração (juros), sejam por meio de contratos com instituições financeiras nacionais e internacionais ${ }^{3}$.

A dívida pública, quando voltada para o desenvolvimento da sociedade, é aceitável e estimulável. Demonstra que o mercado confia no Estado, como devedor que cumpre com suas obrigações. Por isso, quanto melhor for o crédito público, mais possibilidades de serem emprestados recursos financeiros a baixo custo.

Essa é a que chamaremos de dívida pública prudente. Endividamento necessário, sob a Lei de Responsabilidade Fiscal, e que tem como finalidade fazer reproduzir os recursos captados e aplicados, sempre com vista no futuro benefício multiplicado. Uma obra pública - por exemplo, uma estrada - pode trazer muitos benefícios e multiplicar os recursos que foram obtidos no empréstimo.

$\mathrm{Na}$ outra ponta, temos a dívida pública imprudente, que é a que promove danos no futuro. São certas dívidas perpétuas, nas quais somente os juros são pagos, sem qualquer amortização do principal. Ou então, dívidas decorrentes de indenizações, de pagamentos atrasados, decorrentes de atos ilícitos ou de mera gestão deficiente.

O Estado de Direito é o Estado responsável por seus atos. Como estabelece a Constituição da República (CRFB), “[a]s pessoas jurídicas de direito público e as de direito privado prestadoras de serviços públicos responderão pelos danos

2 Sobre os indicadores adotados pelo governo, conferir: ATHAYDE, David Rebelo; VIANNA, André Coelho. Dívida pública brasileira: uma análise comparativa dos três principais indicadores de esforço fiscal do governo. Nova Econ., Belo Horizonte, v. 25, n. 2, p. 403-420, Aug. 2015. Available from: <http://www.scielo.br/scielo.php?script=sci_arttext\&pid=S0103-63512015000200403\&lng =en\&nrm=iso>. Acesso em: 30 ago. 2018. http://dx.doi.org/10.1590/0103-6351/2172.

3 TORRES, Ricardo Lobo. Curso de direito financeiro e tributário. Rio de Janeiro: Renovar, 2008, p. 217. Conferir também: BALEEIRO, Aliomar. Uma introdução à ciência das finanças. Rio de Janeiro: Forense, 2008, p. 545 e ss. 
que seus agentes, nessa qualidade, causarem a terceiros, assegurado o direito de regresso contra o responsável nos casos de dolo ou culpa" (art. 37, $\$ 6^{\circ}$, da CRFB), estando estabelecida a capacidade de o Estado, direta ou indiretamente, ter atribuída responsabilidade por ato ilícito praticado contra outrem.

Nessa toada, assim como qualquer pessoa, o Estado poderá ser condenado ao pagamento de indenizações ou de outras obrigações financeiras pelas mãos do Poder Judiciário. Condenado ao pagamento, deverá satisfazer a dívida, ainda que por procedimento específico. Na nossa classificação, o resultado da condenação judicial será a dívida pública imprudente, advinda de condenação judicial por prática de ato ilícito. É dívida indesejada, que não trará benefício social e será suportada por toda a sociedade.

Dívida judicial do Estado é, pois, o que chamamos coloquialmente de precatórios ${ }^{4}$. Veremos quais são as consequências financeiras decorrentes da dívida pública imprudente, especialmente para Estados e Municípios. Quando em mora - não adimplemento da dívida no tempo correto -, a dívida se expande e se torna de difícil pagamento.

A mora dos entes federativos na obrigação ao pagamento de dívidas judiciais promove prejuízo às suas finanças, além de dificultar a relação entre os poderes Executivo e Judiciário. O acúmulo das dívidas judiciais faz aumentar a dívida pública fundada (ou consolidada), e sua mora causa pagamento de juros. Enfim, não é demais dizer que o atraso se configura como maquiagem contábil, postergando obrigações financeiras do Estado, a fim de apresentar superávits fiscais.

\section{O REGIME DE PRECATÓRIOS NA CONSTITUIÇÃO DE 1988}

Precatórios - ofício-precatório, na verdade - são comunicações encaminhadas pelo Juízo da execução ao Presidente do respectivo Tribunal, solicitando que ele requisite a inclusão na Lei Orçamentária Anual ${ }^{5}$. Trata-se, na teoria, de regime que resulta em respeito à ordem cronológica da apresentação dos precatórios (dos ofícios), preservando o princípio da impessoalidade, evitando a advocacia administrativa $^{6}$.

4 Para entender, consultar: MOREIRA, Egon Bockmann; GRUPENMACHER, Betina Treiger; KANAYAMA, Rodrigo Luís; AGOTTANI, Diogo Zelak. Precatórios: o seu novo regime jurídico. São Paulo: Revista dos Tribunais, 2017.

5 MOREIRA, Egon Bockmann; GRUPENMACHER, Betina Treiger; KANAYAMA, Rodrigo Luís; AGOTTANI, Diogo Zelak. Precatórios: o seu novo regime jurídico. São Paulo: Revista dos Tribunais, 2017, p. 23.

6 PONTES DE MIRANDA, Francisco Cavalcanti. Comentários à Constituição de 1967 com a Emenda n. 1 de 1969. São Paulo: RT, 1970, v. 3, p. 646-647. 
O defeito do regime é que, uma vez ingresso na Lei Orçamentária Anual (LOA), fixando-se dotação para pagamento, inexiste obrigação constitucional para a quitação das dívidas em nosso modelo orçamentário - ou seja, norma que preveja sanção pelo descumprimento. Não há impositividade no adimplemento. E por não haver interesse político no pagamento (certamente, não possui o mesmo impacto político de outras despesas públicas), o acúmulo leva à dívida pública imprudente.

Não obstante as constantes ilegalidades governamentais, o modelo adotado pelo Estado brasileiro para pagamento de dívidas judiciais não é ruim. É lógico. Trata-se de adaptar o adimplemento ao tempo orçamentário estatal, que é cronometrado pela vigência da LOA. Como a CRFB priorizou certas funções estatais em detrimento de outras, o pagamento dos precatórios, em teoria, acontece sem prejuízo às políticas públicas de saúde, educação, segurança pública, serviços públicos em geral.

Os precatórios são pagos no exercício financeiro subsequente ao da comunicação de pagamento pelo Poder Judiciário, se a comunicação ocorrer até o dia $1^{\circ}$ de julho de cada ano $\left(\mathbb{S} 5^{\circ}\right.$ do art. 100 da CRFB). É uma medida salutar para o controle das despesas públicas e no máximo (se cumprida a norma constitucional) atrasará o pagamento até o final do exercício financeiro seguinte. Se cumprida a regra, não haverá prejuízo ao credor.

O montante da dívida cresceu durante os anos da CRFB e era um problema mesmo antes da sua promulgação (vide o art. 33 do Ato das Disposições Constitucionais Transitórias, que permitiu o parcelamento dos precatórios não alimentícios) $)^{7}$. Nos últimos anos, tornou-se um imbróglio aparentemente insolúvel, em razão do acúmulo da dívida nas combalidas finanças públicas.

As alterações da CRFB, no tocante aos precatórios, são sintomáticas. Revelam a permanente inadimplência do Estado, que deixa de honrar suas dívidas judiciais. Desde a promulgação da CRFB, o regime de precatórios vem sofrendo modificações, que ocorreram (e ainda ocorrem) em razão da incapacidade dos governos em cumprir as normas jurídicas e as decisões judiciais.

Quando o regime foi tratado na Assembleia Constituinte, a redação excepcionava da "fila" de precatórios os pagamentos das dívidas de natureza alimentícia. Elas deveriam ser pagas de forma expedita, devido à experiência do Constituinte com o passado inflacionário do $\mathrm{Brasil}^{8}$. De fato, a CRFB foi promulgada com a redação que excluía do regime os pagamentos de natureza alimentícia:

7 E, nesse caso, para pagamento das dívidas, a CRFB autorizou, no parágrafo único do art. 33 do ADCT, a emissão de títulos da dívida pública.

8 Conferir: MOREIRA, Egon Bockmann; GRUPENMACHER, Betina Treiger; KANAYAMA, Rodrigo Luís; AGOTTANI, Diogo Zelak. Precatórios: o seu novo regime jurídico. São Paulo: Revista dos Tribunais, 2017, p. 121. 
Art. 100. À exceção dos créditos de natureza alimentícia, os pagamentos devidos pela Fazenda Federal, Estadual ou Municipal, em virtude de sentença judiciária, far-se-ão exclusivamente na ordem cronológica de apresentação dos precatórios e à conta dos créditos respectivos, proibida a designação de casos ou de pessoas nas dotações orçamentárias e nos créditos adicionais abertos para este fim.

Também na redação original da CRFB, o primeiro parcelamento surgiu no art. 33 do Ato das Disposições Constitucionais Transitórias (ADCT), trazendo a possibilidade de pagamento diferido, em oito anos, da dívida de precatórios não alimentícios. O segundo, no art. 78 do ADCT, acrescentado pela Emenda Constitucional (EC) n. 30/2000, previa, à exceção dos precatórios alimentícios e das requisições de pequeno valor, o parcelamento em dez anos. E o terceiro, o regime especial proporcionado pela EC 62/2009, cujas normas acrescentaram o art. 97 no ADCT. Esta última foi atacada no STF, que o declarou inconstitucional (pelas Ações Diretas de Inconstitucionalidade 4.357 e 4.425).

Mais moderna, veio a Emenda Constitucional n. 94, de 15 de dezembro de 2016, que fez "renascer" a EC n. 62/2009, restabelecendo, em parte, o art. 97 do ADCT, mas seguindo as diretrizes firmadas na ocasião do julgamento das ADIs 4.357 e 4.425 no Supremo Tribunal Federal (STF). E, logo em seguida, sobreveio a EC n. 99, de 14 de dezembro de 2017. Sinteticamente, a EC n. 94 foi mantida com algumas alterações.

\subsection{Alterações no regime ordinário de precatórios - Emendas Constitucionais n. 94 e 99}

O regime de precatórios tornou-se o que não deveria ter se tornado: um modo de postergação do adimplemento da dívida judicial. Em trinta anos de $\mathrm{CRFB}$, os entes federativos sempre se mantiveram alheios às consequências do crescimento da dívida pública, sobretudo a dívida decorrente dos precatórios. Por esse fato, tornou-se grande o suficiente para impossibilitar sua quitação e, por isso, muitas normas constitucionais surgiram. As últimas são as EC n. 94 e 99, promulgadas num interstício de aproximadamente um ano, e suas alterações podem ser assim resumidas (destacamos aqui os pontos relevantes):

A interpretação, já na vigência da Constituição, foi firmada em contrário sentido, pelo STF, nas Ações Diretas de Inconstitucionalidade (ADI) 571-MC e 47, as quais, entre outros julgados, originaram a Súmula 655 (A exceção prevista no art. 100, caput, da Constituição, em favor dos créditos de natureza alimentícia, não dispensa a expedição de precatório, limitando-se a isentá-los da observância da ordem cronológica dos precatórios decorrentes de condenações de outra natureza). 
(a) Art. 100, $\mathbb{S} 2^{\circ}$ (alterado): a Emenda n. 62/2009 estabeleceu novas preferências de precatórios. Agora, em primeiro lugar, receberão os titulares que possuam 60 anos ou mais ou que sejam portadores de doença grave ou portadores de deficiência (conforme definição legal). Após, serão pagos os precatórios alimentícios em geral, e, por último, os precatórios comuns. Em seguida, a EC n. 94/2016 acrescentou que serão beneficiados com a regra da preferência os titulares originários ou por sucessão hereditária, que possuam 60 anos ou mais, ou que sejam portadores de doença grave, ou pessoas com deficiência (estas últimas foram incluídas pela EC n. 94). Vale ressaltar que o pagamento preferencial será “até o valor equivalente ao triplo fixado em lei” ( $\mathbb{S} 2^{\circ}$ do art. 100), ou o quíntuplo no caso de estar o ente federativo sob regime especial (art. 102, $\mathbb{S} 2^{\circ}$ do ADCT, incluído pela EC n. 99).

(b) Art. 100, $\mathbb{S} \mathbb{S} 17,18,19$ e 20 (acrescentados): redação dada pela Emenda 94, os entes federativos (União, Estados, Distrito Federal e Municípios) aferirão mensalmente, em base anual, o comprometimento de suas respectivas receitas correntes líquidas ${ }^{9}$, com o pagamento de precatórios e obrigações de pequeno valor. Na hipótese de o montante total de precatórios e requisições de pequeno valor, considerando a base anual (no período de 12 meses), ultrapassar a média do comprometimento percentual da receita corrente líquida dos 5 anos anteriores, a parcela excedente ao percentual poderá ser financiada, excluindo-se o financiamento dos limites da dívida pública (art. 52, VI e VII da CRFB). É possível, para honrar o financiamento, vincular receita de impostos (criando mais uma exceção à vedação da afetação de receita de impostos, conforme art. 167, IV da CRFB).

Se apresentado um precatório em valor superior a $15 \%$ de todos os precatórios apresentados no respectivo exercício financeiro, $15 \%$ daquele precatório será pago até o exercício seguinte, e o restante em parcelas

9 A Receita Corrente Líquida é definida, para fim de cálculo deste art. 100, pelo $\$ 18$ : "Entende-se como receita corrente líquida, para os fins de que trata o $\$ 17$, o somatório das receitas tributárias, patrimoniais, industriais, agropecuárias, de contribuições e de serviços, de transferências correntes e outras receitas correntes, incluindo as oriundas do $\mathbb{1} 1^{\circ}$ do art. 20 da Constituição Federal, verificado no período compreendido pelo segundo mês imediatamente anterior ao de referência e os 11 (onze) meses precedentes, excluídas as duplicidades, e deduzidas: I - na União, as parcelas entregues aos Estados, ao Distrito Federal e aos Municípios por determinação constitucional; II - nos Estados, as parcelas entregues aos Municípios por determinação constitucional; III - na União, nos Estados, no Distrito Federal e nos Municípios, a contribuição dos servidores para custeio de seu sistema de previdência e assistência social e as receitas provenientes da compensação financeira referida no $\mathbb{S} 9^{\circ}$ do art. 201 da Constituição Federal”. 
iguais nos 5 exercícios subsequentes (com juros de mora e correção monetária). Também se admitem acordos diretos com deságio máximo de $40 \%$ do valor atualizado. É a primeira vez que surge norma de pagamento diferido/parcelado no art. 100 da CRFB. Não se observam defeitos da norma ao prever limites anuais de pagamento de dívidas judiciais, pois sua intenção é manter o equilíbrio fiscal. Entretanto, trata-se de norma com pouca aplicabilidade prática, diante da possibilidade de a Fazenda Pública simplesmente não adimplir sua obrigação de pagamento de precatórios, sem qualquer consequência real.

(c) novo regime especial de precatórios: a EC n. 94 trouxe os arts. 101 a 105 no ADCT. Segundo o novo regime especial, os entes que, em 25 de março de 2015, data da modulação dos efeitos da declaração de inconstitucionalidade em Questão de Ordem nas ADIs 4.425 e 4.357, estiverem em mora com o pagamento de seus precatórios, deverão quitá-los até 31 de dezembro de 2020. Aplicam-se à norma não apenas os antigos precatórios, mas os que vierem a ser apresentados. Recentemente, a EC n. 99/2017 alterou normas inseridas pela EC n. 94/2016, alongando ainda mais o prazo para quitação.

O novo regime especial de precatórios procura, mais uma vez, a resolução do problema causado pela mora no pagamento. Tenta-se elidir a dívida pública imprudente. Diante disso, em apertada síntese, os arts. 101 a 105 do ADCT preveem que os entes federativos que estavam em mora em 25 de março de 2015 depositarão, mensalmente e em duodécimos, em conta especial do Tribunal de Justiça local, percentuais das receitas correntes líquidas, devendo ocorrer a quitação de todos os precatórios até 31 de dezembro de 2024 (incluindo os que deverão ser pagos nesse período) - o deadline foi estendido pela EC n. 99/2017.

Conforme o art. $101, \mathbb{S} 2^{\circ}$, serão fontes de recursos para a quitação: recursos orçamentários; $75 \%$ dos depósitos judiciais e depósitos administrativos, tributários ou não tributários, dos quais os Estados, o Distrito Federal ou os Municípios, ou suas autarquias, fundações e empresas estatais dependentes, sejam parte; até $30 \%$ dos demais depósitos judiciais da localidade, criando-se fundo garantidor; empréstimos, que serão excetuados dos limites ao endividamento ("incisos VI e VII do caput do art. 52 da Constituição Federal e quaisquer outros limites de endividamento previstos em lei”) ${ }^{10}$; depósitos em precatórios e requisições de pequeno valor realizados até 31 de dezembro de 2009 (referem-se a precatórios ou requisições não levantados pelas partes).

10 Preocupante a previsão de endividamento para pagar dívida. Será necessária a regulamentação, para que a nova dívida seja impedida de superar a dívida judicial (precatórios). 
Não ocorrendo a liberação tempestiva dos recursos, o chefe do Poder Executivo responderá por improbidade administrativa e na forma das normas de responsabilidade fiscal. Ademais, os recursos dos Fundos de Participação (dos Municípios - FPM - e dos Estados e Distrito Federal - FPE) servirão ao pagamento da dívida judicial. Salienta-se que, enquanto se mantiver a omissão, o ente não poderá contrair empréstimos ou receber transferências voluntárias, salvo se os empréstimos servirem ao pagamento da própria dívida judicial.

Por último, será facultada aos credores a compensação de precatórios com débitos de natureza tributária ou de outra natureza que foram inscritos em dívida ativa até 25 de março de 2015 (art. 105, caput do ADCT). Às compensações não se aplicarão as vinculações constitucionais (educação, saúde etc.), conforme o art. $105, \mathbb{S} 1^{\circ}$ do ADCT.

\section{(d) dívida pública e novo regime de precatórios}

A atual redação do art. 100 da CRFB e dos arts. 101 a 105 do ADCT alterou, com média profundidade, o pagamento das dívidas judiciais. Para os fins deste texto, interessa, além da própria dívida de precatórios (que é dívida consolidada), a fonte de financiamento para o pagamento.

Não há dúvidas de que o endividamento vem crescendo (em valores nominais), como se observa no Gráfico 1:

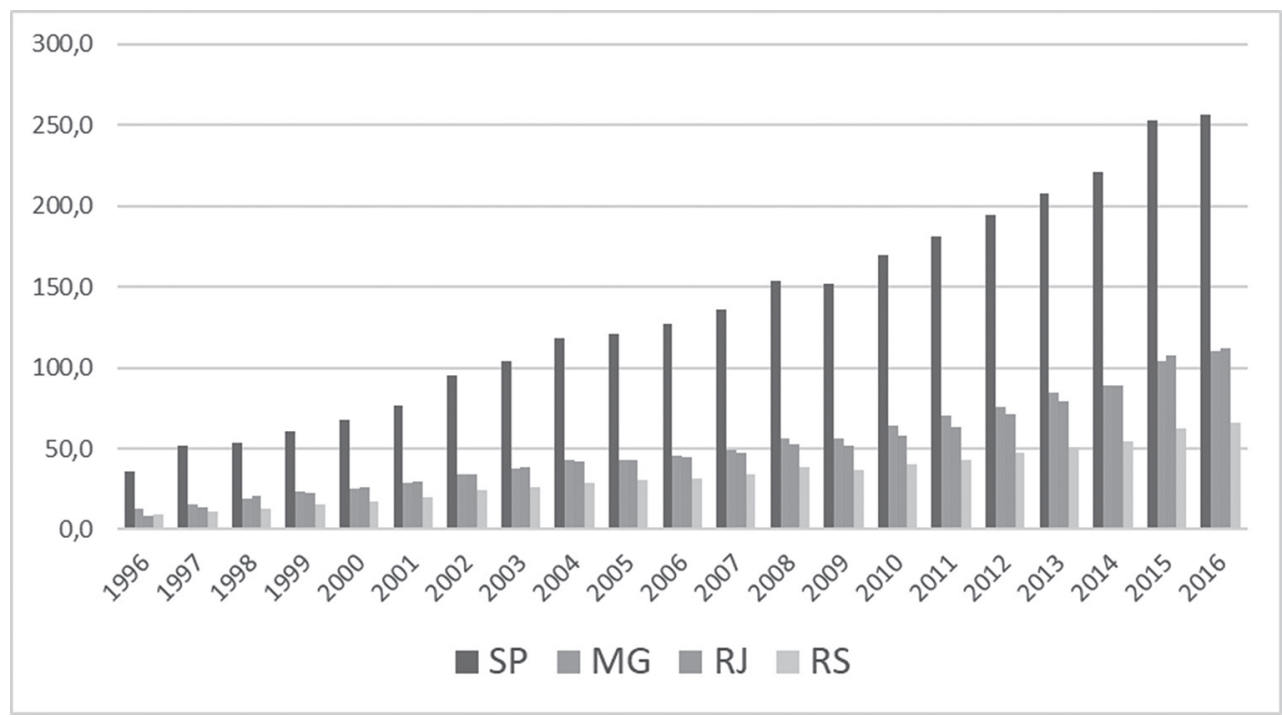

\section{Gráfico 1 - Dívida fundada - Adm. Direta (valores nominais, bilhões R\$)}

Fonte: STN, Tesouro Transparente, Estoque da Dívida de Estados e do Distrito Federal. Disponível em: http://www.tesourotransparente.gov.br/ckan/dataset/estoque-da-divida-de-estados-e-do-distrito-federal. Elaboração dos autores. Acesso em: out. 2018. 
Em razão da progressão da dívida pública consolidada, o regime especial (EC n. 94 e 99) e o regime ordinário (art. 100, após a EC n. 99) estabelecem que:

(i) CRFB

Art. 100 (...)

(...)

\19. Caso o montante total de débitos decorrentes de condenações judiciais em precatórios e obrigações de pequeno valor, em período de 12 (doze) meses, ultrapasse a média do comprometimento percentual da receita corrente líquida nos 5 (cinco) anos imediatamente anteriores, a parcela que exceder esse percentual poderá ser financiada, excetuada dos limites de endividamento de que tratam os incisos VI e VII do art. 52 da Constituição Federal e de quaisquer outros limites de endividamento previstos, não se aplicando a esse financiamento a vedação de vinculação de receita prevista no inciso IV do art. 167 da Constituição Federal.

(ii) ADCT

Art. 101 (...)

(...)

$\mathbb{3} 2^{\circ} \mathrm{O}$ débito de precatórios será pago com recursos orçamentários próprios provenientes das fontes de receita corrente líquida referidas no $\mathbb{S} 1^{\circ}$ deste artigo e, adicionalmente, poderão ser utilizados recursos dos seguintes instrumentos:

III - empréstimos, excetuados para esse fim os limites de endividamento de que tratam os incisos VI e VII do caput do art. 52 da Constituição Federal e quaisquer outros limites de endividamento previstos em lei, não se aplicando a esses empréstimos a vedação de vinculação de receita prevista no inciso IV do caput do art. 167 da Constituição Federal;

Exclui-se do cálculo do endividamento o financiamento para pagamento de precatórios. Em outros termos, em caso de dívida judicial (precatório) que exceda comprometimento da receita corrente líquida, ou dívida judicial em ente federativo que esteja em mora, é possível contrair mais dívida para pagar outra dívida. No entanto, a dívida perdurará - e não se sabe, ainda, sob quais condições, pois a norma constitucional requer regulamentação.

Somando-se toda a dívida dos entes subnacionais, encontramos valores próximos a R\$ 100 bilhões (ver Gráfico 2). Em um momento de crise fiscal, com dificuldades de honrar os pagamentos de pessoal e custeio por alguns Estados e Municípios, a possibilidade de inadimplemento dos precatórios pelos entes nacionais é visível. Possivelmente, inclusive, haverá a pressão dos gestores dos entes subnacionais no Congresso Nacional por futuras alterações constitucionais, seja pelo deslocamento dos débitos para o governo central, seja para a postergação de débitos de precatórios. 


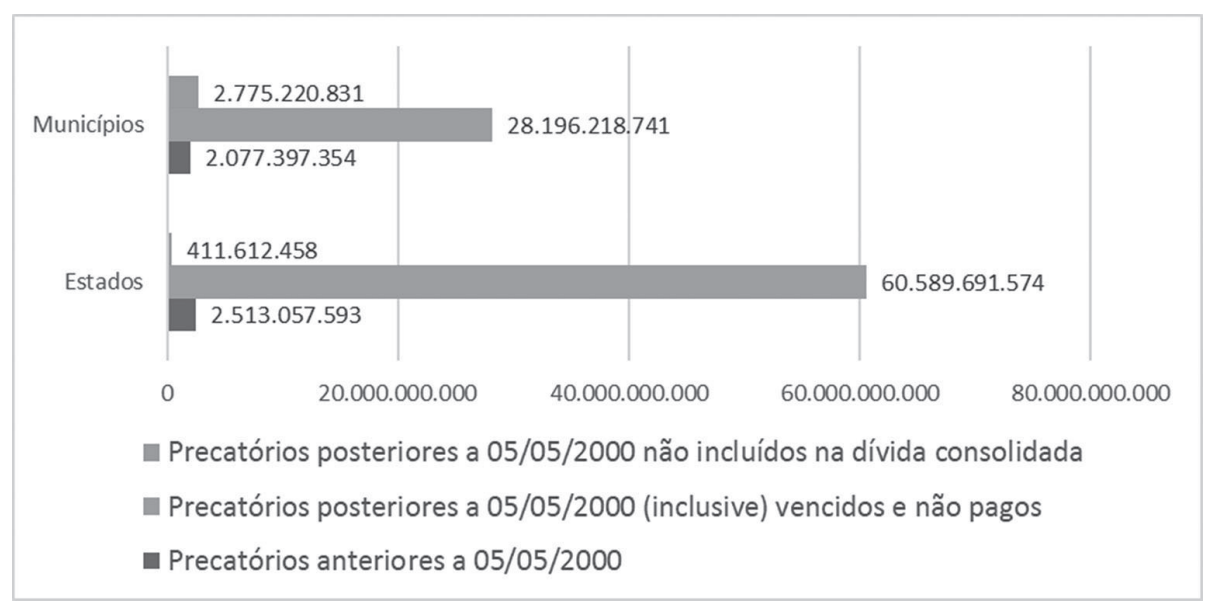

\section{Gráfico 2 - Soma do Saldo Devedor (R\$) - Precatórios dos Estados e Municípios}

Fonte: SADIPEM - Sistema de Análise da Dívida Pública, Operações de Crédito e Garantias da União, Estados e Municípios (julho/2018). Disponível em: https://sadipem.tesouro.gov.br/. Acesso em: 30 ago. 2018.

O total dos precatórios, em julho de 2018, concentra-se em oito Estados (e seus Municípios) - cerca de $90 \%$ do total - ver Gráficos 3 e 4 e Tabela 1 . Mais da metade desses débitos de precatórios concentra-se em São Paulo. Outros sete entes subnacionais (Rio Grande do Sul, Paraná, Bahia, Distrito Federal, Minas Gerais, Rio de Janeiro e Santa Catarina) detêm quase $40 \%$ dos débitos de precatórios restantes. Pela impossibilidade fiscal de algum desses entes no pagamento de débitos e representatividade que possuem na Câmara Federal (mais de 60\%), novas iniciativas legislativas de emendamento constitucional são previsíveis em um futuro próximo.

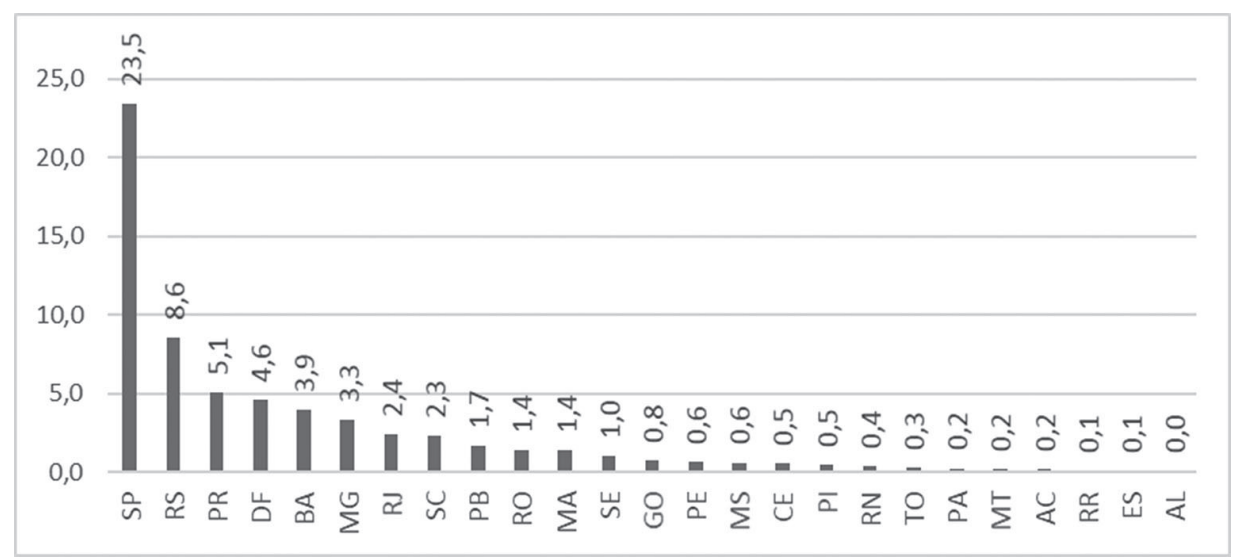

\section{Gráfico 3 - Saldo Devedor (bilhões R\$) - Precatórios dos Estados}

Fonte: SADIPEM - Sistema de Análise da Dívida Pública, Operações de Crédito e Garantias da União, Estados e Municípios (julho/2018). Disponível em: https://sadipem.tesouro.gov.br/. Acesso em: 30 ago. 2018. 
Tabela 1 - Soma do Saldo Devedor (R\$) - Precatórios dos Estados

\begin{tabular}{|c|c|c|c|c|}
\hline ESTADO & $\begin{array}{l}\text { PRECATÓRIOS ANTE- } \\
\text { RIORES A 5/5/2000 }\end{array}$ & $\begin{array}{l}\text { PRECATÓRIOS } \\
\text { POSTERIORES A } \\
\text { 5/5/2000 (INCLU- } \\
\text { SIVE) VENCIDOS E } \\
\text { NÃO PAGOS }\end{array}$ & $\begin{array}{l}\text { PRECATÓRIOS } \\
\text { POSTERIORES A } \\
\text { 5/5/2000 NÃO IN- } \\
\text { CLUÍDOS NA DÍVIDA } \\
\text { CONSOLIDADA }\end{array}$ & TOTAL \\
\hline SP & 229.376 .469 & 23.239.321.612 & & 23.468 .698 .081 \\
\hline RS & & 8.579 .840 .547 & & 8.579 .840 .547 \\
\hline PR & 1.398 .384 .456 & 3.689.456.971 & & 5.087 .841 .427 \\
\hline DF & 804.400 .605 & 3.771 .695 .778 & & 4.576 .096 .384 \\
\hline BA & & 3.933 .020 .801 & & 3.933 .020 .801 \\
\hline MG & & 3.291 .876 .695 & & 3.291 .876 .695 \\
\hline RJ & & 2.428.322.738 & & 2.428 .322 .738 \\
\hline SC & 7.762 .740 & 2.303 .627 .175 & & 2.311.389.915 \\
\hline PB & & 1.650 .836 .887 & & 1.650 .836 .887 \\
\hline RO & & 1.378 .725 .044 & & 1.378 .725 .044 \\
\hline MA & & 1.261 .139 .773 & 110.737 .633 & 1.371 .877 .406 \\
\hline SE & & 1.049 .745 .067 & & 1.049 .745 .067 \\
\hline GO & 39.229 .498 & 726.963 .028 & & 766.192 .526 \\
\hline PE & & 622.448 .962 & & 622.448 .962 \\
\hline MS & & 603.480 .403 & & 603.480 .403 \\
\hline CE & & 524.665 .690 & & 524.665 .690 \\
\hline PI & 24.333 .566 & 450.578 .270 & 978.790 & 475.890 .626 \\
\hline $\mathbf{R N}$ & & 368.132 .896 & & 368.132 .896 \\
\hline то & & 262.953 .642 & & 262.953 .642 \\
\hline PA & & & 245.437 .185 & 245.437 .185 \\
\hline MT & & 181.799.779 & & 181.799.779 \\
\hline AC & 9.570 .258 & 162.306 .539 & & 171.876 .797 \\
\hline RR & & 64.011 .353 & & 64.011 .353 \\
\hline ES & & & 54.458 .851 & 54.458 .851 \\
\hline AL & & 44.741 .922 & & 44.741 .922 \\
\hline Total & 2.513.057.593 & 60.589 .691 .574 & 411.612 .458 & 63.514 .361 .625 \\
\hline
\end{tabular}

Fonte: SADIPEM - Sistema de Análise da Dívida Pública, Operações de Crédito e Garantias da União, Estados e Municípios (julho/2018). Disponível em: https://sadipem.tesouro.gov.br/. Acesso em: 30 ago. 2018. 


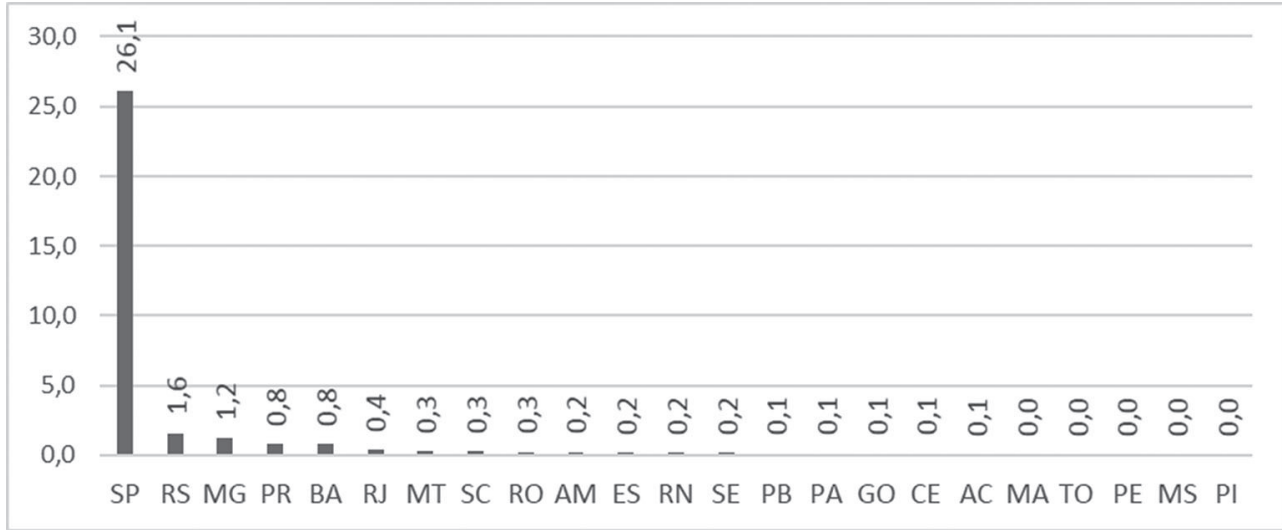

\section{Gráfico 4 - Saldo Devedor (bilhões R\$) - Precatórios dos Municípios (UF)}

Fonte: SADIPEM - Sistema de Análise da Dívida Pública, Operações de Crédito e Garantias da União, Estados e Municípios (julho/2018). Disponível em: https://sadipem.tesouro.gov.br/. Acesso em: 30 ago. 2018.

Diversamente, ainda que possua dívida, a União vem cumprindo com sua obrigação no pagamento de precatórios (Tabela 2 e Gráfico 5). O valor, no entanto, é igualmente vultoso, o que pode revelar problemas na condução de políticas públicas e na atuação dos agentes públicos.

Tabela 2 - Sentenças Judiciais e Soma de Movimento Líquido (R\$)

\begin{tabular}{|c|c|c|c|c|}
\hline $\begin{array}{c}\text { SOMA DE MOVIMENTO LÍQUIDO - } \\
\text { R\$ (ITEM INF.) }\end{array}$ & ANO & & \\
\hline Sentenças judiciais & $\mathbf{2 0 1 5}$ & $\mathbf{2 0 1 6}$ & $\mathbf{2 0 1 7}$ & Total \\
\hline Devidas por empresas estatais & 366.007 .013 & 302.145 .327 & 312.130 .679 & 980.283 .019 \\
\hline Transitadas em julgado (precatórios) & 3.985 .373 .923 & 5.855 .959 .403 & 4.996 .499 .542 & 14.837 .832 .867 \\
\hline Transitadas em julgado de pequeno & 1.241 .680 .492 & 1.358 .694 .087 & 1.427 .138 .747 & 4.027 .513 .325 \\
\hline valor & 5.593 .061 .427 & 7.516 .798 .816 & 6.735 .768 .968 & 19.845 .629 .211 \\
\hline Total
\end{tabular}

Fonte: Tesouro Transparente. Disponível em: http://www.tesourotransparente.gov.br/ckan/dataset/resultado-fiscal-do-governo-central-pessoal-sentencas-judiciais-e-precatorios. Acesso em: julho de 2018. 


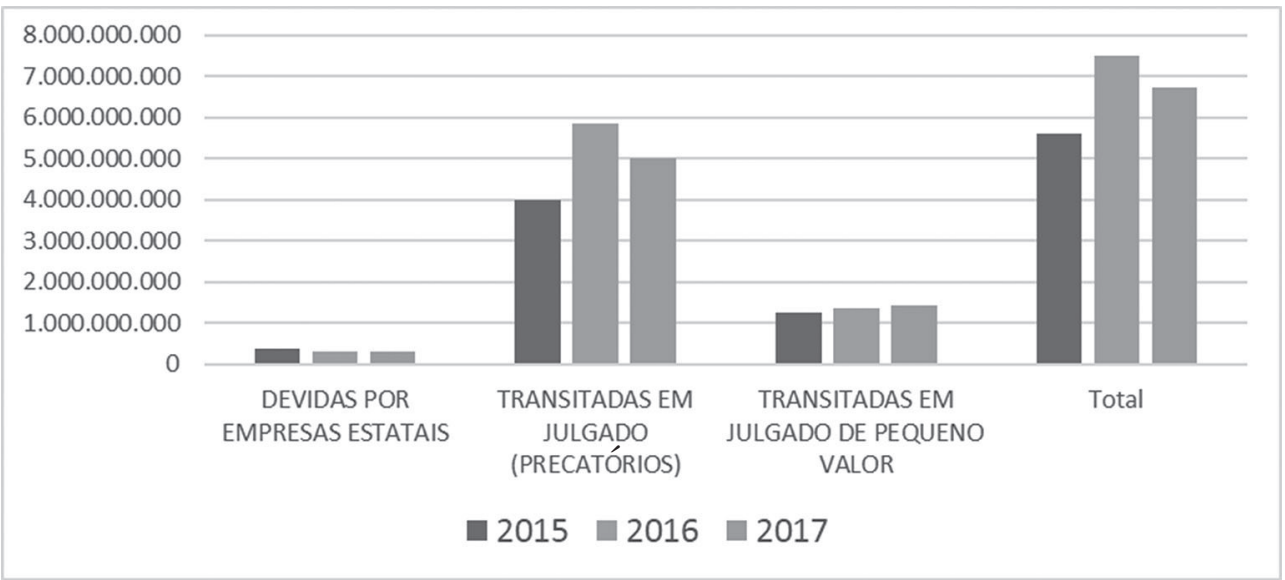

Gráfico 5 - Resultado Fiscal do Governo Central - Sentenças Judiciais e Precatórios (R\$)

Fonte: Tesouro Transparente. Disponivel em: http://www.tesourotransparente.gov.br/ckan/dataset/resultado-fiscal-do-governo-central-pessoal-sentencas-judiciais-e-precatorios. Acesso em: jul. 2018.

Portanto, observam-se dificuldades no pagamento de precatórios em entes subnacionais, cenário diverso do que se percebe nas finanças da União, cujo adimplemento vem ocorrendo. Trata-se claramente de acúmulo de dívidas, que, com o passar dos anos, não foram honradas, por motivos diversos (que podem ser analisados em estudo específico).

\section{CONCLUSÃO}

Após o estudo das informações fiscais, tem-se um ambiente desalentador, com a atuação irresponsável dos entes subnacionais brasileiros. Em razão do histórico perturbador conhecido por quem acompanhou a história constitucional recente (ao menos desde 1988), não serão as medidas advindas das normas das EC n. 94 e 99 que resolverão o imbróglio.

Enquanto não houver impositividade no cumprimento das decisões judiciais que impõem pagamento à Fazenda Pública (como propugna a Proposta de Emenda Constitucional 27/2012, do Senado) ${ }^{11}$, ou sanções políticas aos governos, pouco se pode esperar das medidas aprovadas na CRFB. É possível que a questão permaneça suspensa enquanto viger a EC n. 99, mas que, em futuro próximo,

11 Proposta de Emenda Constitucional 27/2012 - Senado. Disponível em: https://www25.senado. leg.br/web/atividade/materias/-/materia/105884. Acesso em: ago. 2018. 
sobrevenha novo regime, por emendamento constitucional, a fim de dar sobrevida às finanças de entes subnacionais (especialmente Estados endividados).

Dois passos podem trazer a solução para o futuro, para que se preserve a dívida pública prudente. Primeiro, o adimplemento de todo o estoque da dívida (seja por pagamento, transação, compensação, parcelamento). Segundo, a criação de norma que imponha o pagamento da dívida judicial (ponderando o cumprimento das decisões com a solvência do Estado), estipulando obrigações e sanções.

\section{REFERÊNCIAS}

ATHAYDE, David Rebelo; VIANNA, André Coelho. Dívida pública brasileira: uma análise comparativa dos três principais indicadores de esforço fiscal do governo. Nova Econ., Belo Horizonte, v. 25, n. 2, p. 403-420, Aug. 2015. Available from <http:// www.scielo.br/scielo.php?script=sci_arttext $\&$ pid=S0103-63512015000200403\&lng=en \&nrm=iso>. Acesso em: 30 ago. 2018. http://dx.doi.org/10.1590/0103-6351/2172

BALEEIRO, Aliomar. Uma introdução à ciência das finanças. Rio de Janeiro: Forense, 2008 .

MOREIRA, Egon Bockmann; GRUPENMACHER, Betina Treiger; KANAYAMA, Rodrigo Luís; AGOTTANI, Diogo Zelak. Precatórios: o seu novo regime jurídico. São Paulo: Revista dos Tribunais, 2017.

PONTES DE MIRANDA, Francisco Cavalcanti. Comentários à Constituição de 1967 com a Emenda n. 1 de 1969. São Paulo: RT, 1970.

TORRES, Ricardo Lobo. Curso de direito financeiro e tributário. Rio de Janeiro: Renovar, 2008.

VILLEGAS, Héctor Belisario. Curso de finanzas, derecho financeiro y tributário. 9. ed. Buenos Aires: Astrea, 2009. 
